\title{
Are Tax Incentive Provisions Always Operative? Evidence From The Greek Manufacturing Industry
}

Thomas A. Anastassiou, (Email: anastassiou@aueb.gr), Athens University of Economics and Business, Greece

\begin{abstract}
Tax incentives have been provided in many countries with the ultimate goal of making the cost of capital cheaper and thus enabling the development process through the increase of investment expenditures. The study of the role of tax incentives in investment spending has been made possible through the use of the neoclassical theory of optimum capital accumulation. This theory has been used in this article to indicate that incentive provisions may not always be operative at the margin, and thus having no effect in the formulation of the value of depreciation allowances and further on the value of the implicit rental price of capital. Variations in the value of the user cost of capital can make an investment project cheaper or more expensive in relation to various time periods. This could not be proved for the case of Greece.
\end{abstract}

\section{INTRODUCTION}

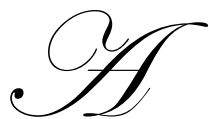

$\mathrm{s}$ it is known, the flexible accelerator theory and its various variants have indicated as an important investment determinant of the optimum capital stock the expected level of production and sales, and they have further considered in their exposition a fixed capital-output ratio. A step further is the neoclassical theory of optimal capital accumulation, as developed by Jorgenson $(1965,1967,1974)$ and his associates ${ }^{1}$, in which they attribute a special role to relative prices and tax incentives as important investment determinants.

In relevance to this theory and using Jorgenson's terminology, $\mathrm{z}$ represents all those fiscal instruments used at different times, which, when reduced to a present value, will provide a means of calculating an implicit cost for capital services. The calculated values of $\mathrm{z}$ have presupposed that firms profits are enough to absorb all the allowances available to them. In this article an enquiry is made into restrictions on the availability of tax allowances that have been provided over an earlier period in Greece in affecting the value of $\mathrm{z}$, and this introduces new grounds in the evaluation of incentive provisions through the use of the neoclassical theory.

\section{PRESENT VALUE OF DEPRECIATION ALLOWANCES ON ONE UNIT INVESTMENT, Z}

When firms are planning their investment projects two important determinants of their investment cost that should be considered among others are depreciation allowances and the other tax allowances of tax-free reserves, investment deductions and investment allowances. Every incentive system provides for these measures with an ultimate goal of making the cost of investment cheaper than it otherwise would have been.

Using the neoclassical framework, for every unit of investment, the firm is entitled to deduct from taxable income in successive years a stream of depreciation allowances, $d_{1}, d_{2}, d_{3}, \ldots \ldots, d_{n}$, whose present value, denoted by $z$, is given by

$$
z=\frac{d_{1}}{(1+r)}+\frac{d_{2}}{(1+r)^{2}}+\frac{d_{3}}{(1+r)^{3}}+\ldots+\frac{d_{n}}{(1+r)^{n}},
$$


or $z=\sum_{i=1}^{n} \frac{d_{i}}{(1+r)^{i}}$

with $r$ being the rate of discount.

Given the value of $\mathrm{z}$, if the revenues of a firm are taxed at rate $\mathrm{t}$, then $\mathrm{tz}$ will represent the discounted value of tax savings which are expected to follow from a unit value of fixed investment. Furthermore, variations in the value of $\mathrm{z}$, when $\mathrm{t}$ is constant (or nearly constant, as it is found to be the case in Greece during the sample period), will make the implicit rental price of capital (c) vary, thus making an investment project cheaper or more expensive in relation to various time periods.

In Table (1), using the depreciation rates for tax purposes ${ }^{2}$, and for Area A (Athens-Piraeus and surrounding areas comprising the Department of Attica), the corresponding values of $\mathrm{z}$ have been calculated for equipment and buildings. It was chosen to report on Area A, since it is believed (and there are a lot of indications to support this supposition $)^{3}$ that the representative firm is situated in the Attica Department. The discount rate used was taken to be an annual average of the long term loans interest rate for manufacturing, supplied by the Bank of Greece, as depreciation deductions are expressed in nominal terms.

The values of $\mathrm{z}$ for equipment are generally higher than those for buildings given the sorter useful life for tax purposes recognized for these assets. In addition one can observe from a diagrammatic representation of the trend of $\mathrm{z}$ since 1950 (see Figures 1 and 2), that most of the time $\mathrm{z}$ has remained virtually constant with no serious fluctuations that could cause important changes in the value of the user cost of capital.

\section{OTHER TAX ALLOWANCES AND THE VALUE OF $\mathrm{Z}$}

The incorporation of any other allowances provided by the tax system can now be introduced. Reference will be made at present to tax-free reserves, investment deductions, and investment allowances that have been provided by the Greek tax system ${ }^{4}$. One has to consider again the present value of these allowances which will always be related to the acquisition value of the assets and not to asset prices prevailing in the period these allowances are calculated. Since it has been simply supposed that the current investment outlay is one unit, an investment allowance for example will be given as a percentage of the original unit investment expenditure that is deductible from this year's net profits.

The provisions for tax-free reserves and investment deductions cannot be incorporated mechanistically into the calculation of z. These two provisions are completely dependent on the amount of net profits. A 100 per cent deduction of net profits completely deprived tax authorities of any tax revenues from new investments. Similarly, a 50 per cent deduction of net profits before 1967 for the representative firm, could have had the same results on government revenue if one considers also the various depreciation allowances in use at that time ${ }^{5}$. Mainly after 1972, when all these net profit deduction provisions were abolished, and the new system of investment allowances started to be applied, corporate tax-revenues began to increase substantially given also that no investment allowances were available for the representative firm of Area A.

Considering the amount of investment deductions claimed in each year, and the corresponding yearly figures of investment expenditures, one could find the actual values of investment allowances applied each year, but these figures could have had no practical meaning, being ex post to the entrepreneur who was interested in planning his investment policy on the tax incentive provisions that actually affected the value of his implicit rental price of capital.

If one denotes by $\lambda$ the value of investment allowance (started to be applied after 1973) that could be claimed on every unit of investment expenditure, then

$$
z=\sum_{i=1}^{n} \frac{d_{i}}{(1+r)^{i}}+\lambda
$$


since, according to the Greek incentive system, investment allowances could be claimed in addition to depreciation allowances.

Table 1:

Present Value Of Depreciation Allowances On A Unit Investment In Equipment And Buildings, Area A, 1950-1982

\begin{tabular}{|c|c|c|c|c|c|c|c|}
\hline \multirow[b]{2}{*}{ Year } & \multicolumn{3}{|c|}{ Equipment } & \multicolumn{3}{|c|}{ Build ings } & \multirow[b]{2}{*}{$\begin{array}{l}\text { Dis- } \\
\text { count } \\
\text { Rate }(\%)\end{array}$} \\
\hline & $\begin{array}{l}\text { Depre- } \\
\text { ciation } \\
\text { Rate }\left(\mathrm{d}_{\mathrm{i}}\right)\end{array}$ & $\begin{array}{l}\text { Tax } \\
\text { Life } \\
\left(n_{i}=\frac{1}{d_{i}}\right)\end{array}$ & $\sum_{i=1}^{n} \frac{d_{i}}{(1+r)^{i}}=z$ & $\begin{array}{l}\text { Depre- } \\
\text { ciation } \\
\text { Rate }\left(\mathrm{d}_{\mathrm{i}}\right)\end{array}$ & $\begin{array}{l}\text { Tax } \\
\text { Life } \\
\left(n_{i}=\frac{1}{d_{i}}\right)\end{array}$ & $\sum_{i=1}^{n} \frac{d_{i}}{(1+r)^{i}}=z$ & \\
\hline 1950 & 0.2000 & 5.00 & 0.7209 & 0.1000 & 10.00 & 0.5650 & 12.00 \\
\hline 1951 & 0.2000 & 5.00 & 0.7209 & 0.1000 & 10.00 & 0.5650 & 12.00 \\
\hline 1952 & 0.2000 & 5.00 & 0.7209 & 0.1000 & 10.00 & 0.5650 & 12.00 \\
\hline 1953 & 0.2000 & 5.00 & 0.7209 & 0.1000 & 10.00 & 0.5650 & 12.00 \\
\hline $1954^{1}$ & 0.2000 & 5.00 & 0.7582 & 0.1000 & 10.00 & 0.6145 & 10.00 \\
\hline $1954^{2}$ & 0.1400 & 7.14 & 0.7525 & 0.0750 & 13.33 & 0.5538 & 10.00 \\
\hline 1955 & 0.1400 & 7.14 & 0.7803 & 0.0750 & 13.33 & 0.5853 & 9.00 \\
\hline 1956 & 0.1400 & 7.14 & 0.7525 & 0.0750 & 13.33 & 0.5538 & 10.00 \\
\hline 1957 & 0.1400 & 7.14 & 0.7525 & 0.0750 & 13.33 & 0.5538 & 10.00 \\
\hline 1958 & 0.2100 & 4.76 & 0.7991 & 0.1125 & 8.89 & 0.6484 & 10.00 \\
\hline 1959 & 0.2100 & 4.76 & 0.8429 & 0.1125 & 8.89 & 0.7056 & 7.92 \\
\hline 1960 & 0.2100 & 4.76 & 0.8635 & 0.1125 & 8.89 & 0.7334 & 7.00 \\
\hline 1961 & 0.2100 & 4.76 & 0.8635 & 0.1125 & 8.89 & 0.7334 & 7.00 \\
\hline 1962 & 0.2100 & 4.76 & 0.8635 & 0.1125 & 8.89 & 0.7334 & 7.00 \\
\hline 1963 & 0.2100 & 4.76 & 0.8635 & 0.1125 & 8.89 & 0.7334 & 7.00 \\
\hline 1964 & 0.2100 & 4.76 & 0.8635 & 0.1125 & 8.89 & 0.7334 & 7.00 \\
\hline 1965 & 0.2100 & 4.76 & 0.8635 & 0.1125 & 8.89 & 0.7334 & 7.00 \\
\hline 1966 & 0.2100 & 4.76 & 0.8522 & 0.1125 & 8.89 & 0.7181 & 7.50 \\
\hline 1967 & 0.2100 & 4.76 & 0.8522 & 0.1125 & 8.89 & 0.7181 & 7.50 \\
\hline 1968 & 0.2100 & 4.76 & 0.8522 & 0.1125 & 8.89 & 0.7181 & 7.50 \\
\hline 1969 & 0.2100 & 4.76 & 0.8522 & 0.1125 & 8.89 & 0.7181 & 7.50 \\
\hline 1970 & 0.2100 & 4.76 & 0.8522 & 0.1125 & 8.89 & 0.7181 & 7.50 \\
\hline 1971 & 0.2100 & 4.76 & 0.8522 & 0.1125 & 8.89 & 0.7181 & 7.50 \\
\hline 1972 & 0.2100 & 4.76 & 0.8522 & 0.1125 & 8.89 & 0.7181 & 7.50 \\
\hline 1973 & 0.1875 & 5.33 & 0.8666 & 0.1000 & 10.00 & 0.6635 & 8.25 \\
\hline 1974 & 0.1875 & 5.33 & 0.8119 & 0.1000 & 10.00 & 0.6015 & 10.50 \\
\hline 1975 & 0.1875 & 5.33 & 0.8119 & 0.1000 & 10.00 & 0.6015 & 10.50 \\
\hline 1976 & 0.1875 & 5.33 & 0.8119 & 0.1000 & 10.00 & 0.6015 & 10.50 \\
\hline 1977 & 0.1875 & 5.33 & 0.8119 & 0.1000 & 10.00 & 0.6015 & 10.50 \\
\hline 1978 & 0.1875 & 5.33 & 0.7985 & 0.1000 & 10.00 & 0.5867 & 11.09 \\
\hline 1979 & 0.1875 & 5.33 & 0.7385 & 0.1000 & 10.00 & 0.5232 & 13.92 \\
\hline 1980 & 0.1875 & 5.33 & 0.6639 & 0.1000 & 10.00 & 0.4494 & 18.00 \\
\hline 1981 & 01875 & 5.33 & 0.6639 & 0.1000 & 10.00 & 0.4494 & 18.00 \\
\hline $1982^{1}$ & 0.1875 & 5.33 & 0.6989 & 0.1000 & 10.00 & 0.4833 & 16.00 \\
\hline $1982^{2}$ & 0.1800 & 5.35 & 0.6707 & 0.0960 & 10.42 & 0.4844 & 16.00 \\
\hline
\end{tabular}

Source: For depreciation rates see incentive laws reported in text. For discount rates see Bank of Greece, Monthly Statistical Bulletin, various issues.

${ }^{1}$ First two quarters,

${ }^{2}$ Last two quarters. 
Figure 1:Value Of Z For Manufacturing Investment In Equipment, Area A,1950-1982

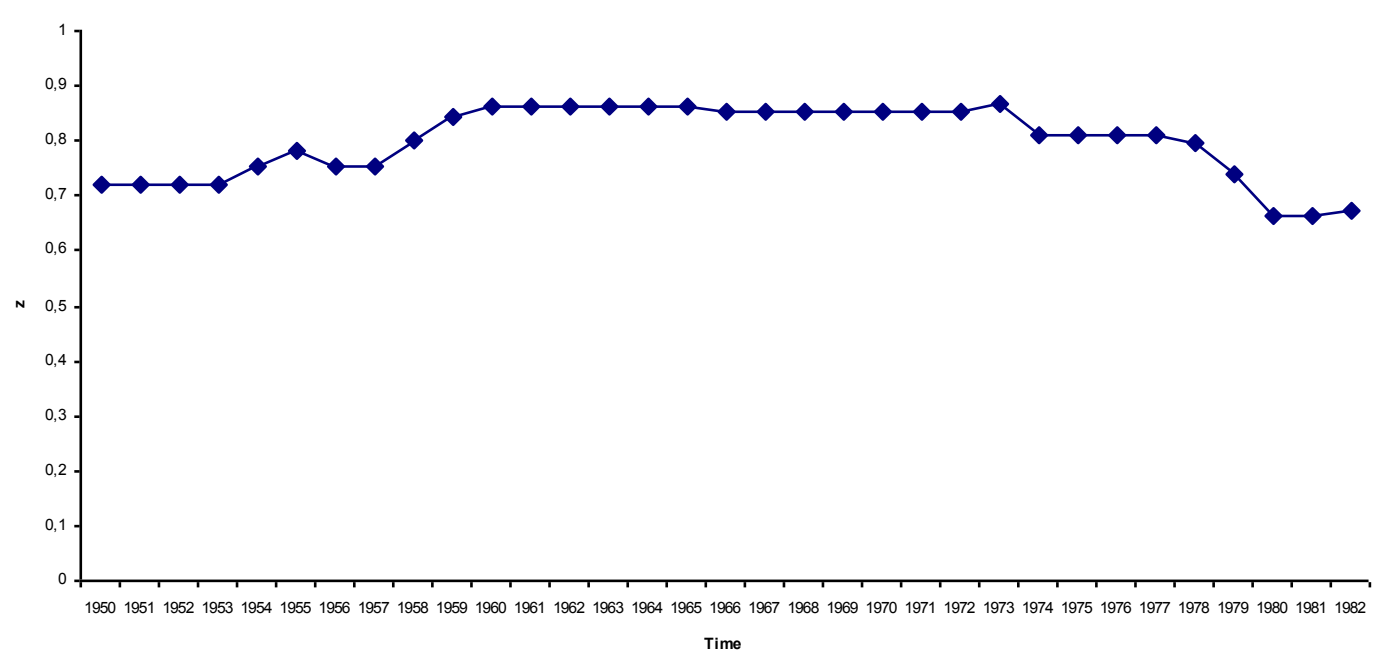

Figure 2: Value Of Z For Manufacturing Investment In Buildings, Area A,1950-1982

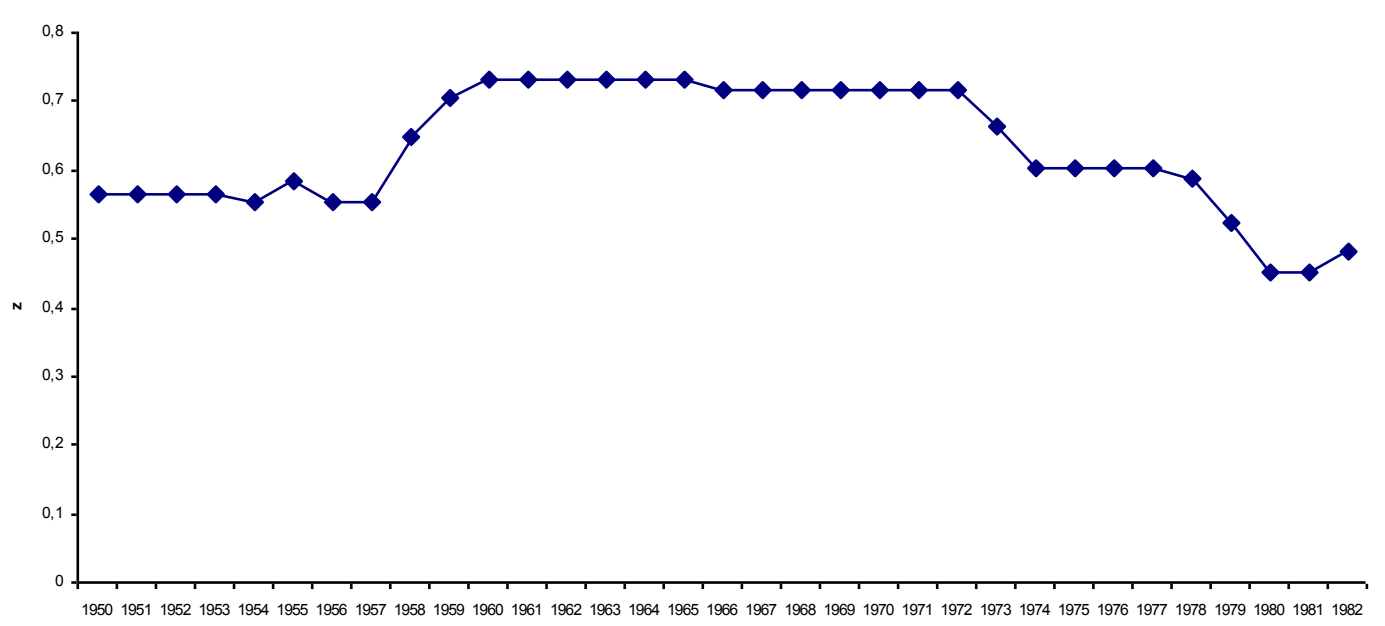

Using the various investment allowance percentages supplied by the various incentive laws in effect at that time and for the representative firm of Area $\mathrm{A}^{6}$, the following new values of $\mathrm{z}$ are found.

Since investment allowances entitle the firm to deduct a specific proportion of the original cost of the asset, without requiring this proportion to be deducted from the depreciable base of the asset in the following years (as it is the case with initial allowances), the summation of investment allowances and annual allowances (formula 3 above) can quite well be greater than one. This is indeed the case for the value of $\mathrm{z}$ for equipment in years 1974 , 1975 and 1978. These values could mean, if they are in fact operative ${ }^{7}$, that a unit of current investment entitles the firm to deduct from its net profits greater amount than the cost of the asset itself. The case could become more intensified if the greater percentages of investment allowances for regions other than Area A are applied. 
Table 2:

The Value Of $\mathrm{Z}$ Including Investment Allowances

\begin{tabular}{|c|c|c|}
\hline Year & Equipment & Buildings \\
\hline 1974 & 1.2119 & \\
1975 & 1.2119 & 0.8367 \\
1976 & & 0.7732 \\
1977 & & 0.6994 \\
1978 & 1.0485 & 0.6494 \\
1979 & 0.9885 & 0.6833 \\
1980 & 0.9139 & 0.8639 \\
1981 & 0.8989 & \\
\hline
\end{tabular}

Source: Table (1) and incentive laws as reported in note No 6.

*First two quarters.

\section{NET PROFITS AND INVESTMENT ALLOWANCES}

The derivation of a time series of $\mathrm{z}$ values for the Greek manufacturing industry presupposed that all firms faced the same discount rate and their profits were enough to absorb the allowances available to them. But what if one of these conditions does not hold? In this section the inoperative nature of investment allowances in relation to net profits for the Greek corporation will be shown, providing thus a new base for a further assessment of the Greek tax incentive structure. The fundamental point reached in this section is that profit restrictions could have been a binding constraint which may have prevented investment allowances from being claimed on marginal projects. The inoperative nature of investment allowances is suggested by comparing manufacturing investment outlays and the maximum amount of net profits that could be deducted each year for investment expenditures. The later figures (derived from the application of tax allowances to the amount of net profits as defined by Greek law) were found to be on average much lower than gross investment realized each year, suggesting the ineffectiveness of incentive provisions at the margin.

It should be acknowledged that the following discussion suggests and does not prove that Greek incentives were ineffective during the 1958-1980 period. The comparisons required for such a suggestion have been made on an aggregate level and with respect to a (hypothetical) representative firm as is usually done in the literature. It is admitted that the representative firm scenario avoids all serious aggregation problems, but for our case there was unfortunately no data on the distribution of profits among firms to provide any additional evidence on the issue under investigation. It could have been possible of course that even when aggregate profits were low, some firms had high profits (where incentives could have been operative) while others had had negative profits (where incentives could not affect their marginal investment decisions). What is true of the 'representative firm' need not apply to all firms. No absolute proof on the matter can be given. We continue the discussion in the present section bearing in mind that aggregate figures have been used throughout all comparisons.

For the derivation of net profits, it is specified by the Greek tax law ${ }^{8}$ that investment allowances applied on investment outlays 'shall be deducted from net profits' which are further defined as those 'shown in the books after deducting provisions for ordinary reserves, compulsory distribution of dividends to shareholders or payments to partners in the case of personal or individual companies or limited liability partnerships'.

Legal or statutory reserves should account for five per cent of a company's profits, and are set aside each year until this reserve amounts to one-third of share capital. Compulsory dividend should be, each year, at least six per cent of paid-up capital.

Data for net income and dividend distribution of Greek owned corporations are provided annually by the National Statistical Service of Greece (NSSG) in its 'Declared Income Statistics of Legal Entities'. These figures referring to manufacturing and other sectors of economic activity cover Greek owned corporations while our concern 
at present is on large scale manufacturing (irrespective of legal form). Data on manufacturing in the above sense are reported in the NSSG's 'Annual Industrial Surveys'. But while complete data on industrial production, employment, and asset formation are reported in these surveys, no figures for net or even gross profits and dividend distribution are provided. To derive first a gross profit series we have used the reported data on value-added for large scale manufacturing (i.e. establishments employing more than ten people). When total consumption of raw materials, packing materials, spare parts, fuel, electric energy, etc., are deducted from gross production value, the derived figure of value-added further reduced by the labor costs will give us a good approximation of gross profits. For the amount of labor costs care has been taken to include, in addition to annual remuneration of wage earners and salaried employees, the corresponding employer's social insurance contributions ${ }^{9}$.

This gross profit figure in addition to depreciation will include also other 'various expenses', as interest payments, marketing expenses, administrative expenses, etc. Since the NSSG's Surveys do not report specifically on these expenses, reference was made to corresponding data from the Federation of Greek Industries (FGI) for a final derivation of net profits before dividend distribution ${ }^{10}$. A linear regression was run on the last data between general expenses and gross profits to define the relative percentage to be used in the NSSG's gross profit data. General expenses (including depreciation) were found to be 90 per cent of gross profits, while this percentage was reduced to 70 per cent when depreciation was excluded from general expenses ${ }^{11}$. General expenses covering 90 per cent of gross profits is indeed a very large amount and hardly represents reality but this is indeed the situation in Greek practice where entrepreneurs can virtually put into this category of 'various expenses' whatever expenses they can think of, within of course the limits of the law, so that they can reduce profits to the smallest possible amount. For our purposes of the derivation of net profits, since the law specifically states as net profits to be those 'shown in the books', we have to abide by the previous derivation since this will be the figure on which further reductions will be made by the application of investment allowances.

To have the net profit figure before the application of investment allowances, dividend distribution have also to be deducted. Since no dividend figures are supplied by the NSSG's Surveys, reference to data from the Federation of Greek Industries was made. This indicated that around 7 per cent of gross profits (being the main determinant in payout decisions) were allocated each year for dividends ${ }^{12}$. So, using the total 97 per cent $(90$ per cent general expenses $^{13}$, and 7 per cent dividends) on the NSSG's gross profits data we have derived in Table (3), Column 2, the required net profits series. The immediate task is to compare them with the amounts of investment expenditures undertaken in relevant years. The available statistics for large scale manufacturing and for new items plus any imported used items ${ }^{14}$, which represent the 'productive investments' as required by the various incentive laws, are given for the years 1958-1977 and are reproduced in Column 1 of Table (3). The percentages of investment deductions ${ }^{15}$ up to 1972 were applied then to net profit figures, giving thus the maximum amounts of net profits that would be deducted each year for investment expenditures. These figures were much lower than gross investment (compare Columns 1 and 5) indicating for the representative firm the ineffectiveness of these incentive provisions on marginal investments (i.e. investments at the margin, towards which the incentive structure is referred). In other words, marginal investments were not benefiting from any investment deductions while at the same time the government was losing revenues.

After 1972 we have investment allowances that were applied for the representative firm in the years 1974, 1975, and in the years after 1978. For 1974 and 1975 the investment allowances were applicable only to gross investment for machinery. In addition the incentive laws imposed a restriction on the maximum permissible amount that could be deducted from net profits. Applying these specifications it is found again (compare Columns 5 and 7) that the amounts of net profits were not enough to absorb the available investment allowances. In other words investment allowances were not operative at the margin for the (hypothetical) representative firm.

Examining the operative nature of investment allowances on a regional level, it is obvious that the procedure could have been as before if there were available figures for investment and net profits for the various Areas. Since these were not available, another method was used for comparison. It was calculated for the total of the period what percentage on the average net profits bear to the amount of gross investment. This is found to be around 7.4 per cent (see Column 3, Table 3). For investment allowances not to be binding the net profit 'restriction' had to be 100 per cent (or in this case no restriction at all) and the percentage of investment allowances less than 7.4 per cent. But looking at 
the investment allowance percentages provided by various incentive laws of Areas B, C, D, E, no percentage of investment allowance is found less than 7.4 per cent not to mention the net profit restrictions that every so often were imposed by the various incentive laws. So, a further proof at the regional level indicates the non operative nature of investment allowances. Of course one should admit that this method is very general since investment and profit figures that are employed refer to total Greece and no indication is provided on individual Area figures.

Table 3:

Net Profits And Investment Expenditures - Comparison Procedure One (In Million Drs, At Current Prices)

\begin{tabular}{|c|c|c|c|c|c|c|c|c|c|c|c|}
\hline \multirow[t]{2}{*}{ Year } & \multirow{2}{*}{$\begin{array}{l}\text { Gross } \\
\text { Invest- } \\
\text { ment } \\
\text { (1) }\end{array}$} & \multirow{2}{*}{$\begin{array}{l}\text { Net } \\
\text { Profits } \\
(2)\end{array}$} & \multirow{2}{*}{$\begin{array}{l}\frac{(2)}{(1)} \\
\% \\
(3)\end{array}$} & \multirow{2}{*}{$\begin{array}{l}\text { Net Profit } \\
\text { Allow- } \\
\text { ance\% } \\
\text { (4) }\end{array}$} & \multirow{2}{*}{$\begin{array}{l}\text { Tax } \\
\text { Exempted } \\
\text { Net Profits } \\
(5)\end{array}$} & \multicolumn{2}{|c|}{$\begin{array}{l}\text { Investment } \\
\text { Allowances }\end{array}$} & \multirow{2}{*}{$\begin{array}{l}\text { Required } \\
\text { Net } \\
\text { Profits } \\
(8)\end{array}$} & \multirow{2}{*}{$\begin{array}{l}\text { Gross } \\
\text { Profits } \\
(9)\end{array}$} & \multirow{2}{*}{$\begin{array}{l}\frac{(8)}{(9)} \\
(10)\end{array}$} & \multirow{2}{*}{$\begin{array}{l}\text { General } \\
\text { Ex- } \\
\text { pences }^{3} \\
(\%) \\
(11)\end{array}$} \\
\hline & & & & & & $\begin{array}{l}\%) \\
(6)\end{array}$ & $\begin{array}{l}\text { Amount } \\
\text { (7) }\end{array}$ & & & & \\
\hline 1958 & 1342 & 120 & 8.9 & ---- & ---- & & & ---- & 3986 & & \\
\hline 1959 & 1162 & 135 & 11.6 & 50.0 & 67.5 & & & 2324 & 4505 & 51.6 & 44.6 \\
\hline 1960 & 1333 & 156 & 11.7 & 50.0 & 78 & & & 2666 & 5206 & 51.2 & 44.2 \\
\hline 1961 & 2083 & 160 & 7.7 & 50.0 & 80 & & & 4166 & 5325 & 78.2 & 71.2 \\
\hline 1962 & 3027 & 182 & 6.0 & 50.0 & 91 & & & 6054 & 6071 & 99.7 & 92.7 \\
\hline 1963 & 2959 & 221 & 7.5 & 50.0 & 110.5 & & & 5918 & 7379 & 80.2 & 73.2 \\
\hline 1964 & 3268 & 244 & 7.5 & 50.0 & 122 & & & 6536 & 8126 & 80.4 & 73.4 \\
\hline 1965 & 8325 & 291 & 3.5 & 50.0 & 145.5 & & & 16650 & 9702 & 171.6 & 164.6 \\
\hline 1966 & 4475 & 330 & 7.4 & 50.0 & 165 & & & 8950 & 11012 & 81.3 & 74.3 \\
\hline 1967 & 4695 & 349 & 7.4 & 50.0 & 174.5 & & & 9390 & 11635 & 80.7 & 73.7 \\
\hline 1968 & 4511 & 406 & 9.0 & 100.0 & 406 & & & 4511 & 13539 & 33.3 & 26.3 \\
\hline 1969 & 5565 & 524 & 9.4 & 100.0 & 524 & & & 5565 & 17464 & 31.9 & 24.9 \\
\hline 1970 & 9094 & 696 & 7.7 & 100.0 & 696 & & & 9094 & 23188 & 39.2 & 32.2 \\
\hline 1971 & 12036 & 784 & 6.5 & 100.0 & 784 & & & 12036 & 26122 & 46.1 & 39.1 \\
\hline 1972 & 18201 & 829 & 4.0 & 100.0 & 829 & & & 18201 & 27639 & 65.8 & 58.8 \\
\hline 1973 & 18593 & 1270 & 6.8 & --- & --- & & & --- & 42346 & & \\
\hline 1974 & $13805^{1}$ & 1537 & $6.2^{2}$ & 50.0 & 768.5 & 40.0 & 5522.0 & 11044 & 51225 & 21.5 & 14.5 \\
\hline 1975 & $15871^{1}$ & 1529 & $5.7^{2}$ & 50.0 & 764.5 & 40.0 & 6348.4 & 12696 & 50965 & 24.9 & 17.9 \\
\hline 1976 & 31250 & 1839 & 5.9 & --- & --- & & & --- & 61302 & & \\
\hline 1977 & 31790 & 2061 & 6.5 & --- & --- & & & --- & 68687 & & \\
\hline$\%$ & Average & & 7.4 & & & & & & & & 57.8 \\
\hline
\end{tabular}

Source: National Statistical Service of Greece, Annual Industrial Surveys, Athens, annual series, Federation of Greek Industries, The State of Greek Industry, Athens, annual series, and derivations described in text.

\footnotetext{
${ }^{1}$ Refers to investment in equipment

${ }^{2}$ Percentages refer to total manufacturing

${ }^{3}$ Percentages of Column (10), reduced by a $7 \%$ dividend rate.
}

To further assess the validity of the above arguments another but less precise data source (that could extend the comparisons beyond 1977) was used. The results that were derived were again the same. These data employed directly the net income and dividend distribution figures of the NSSG's 'Declared Income Statistics of Legal Entities' series. Taking the figures of 'total net income after revision' according to tax legislation and deducting the 5 per cent for legal reserves and the amounts of distributed profits in each year, net profit figures were derived to which the various investment deductions and investment allowances could be applied (the final figures are given in Columns 3 and 4 of Table 4$)$. 
These figures refer not only to manufacturing but also to other sectors of economic activity. If reference were to be made only to manufacturing the above net profit figures would have to be reduced substantially (even below 50 per cent since manufacturing and handicraft activities comprise an average 43 per cent ${ }^{16}$ of the total amounts of profits made by all sectors). On the other hand, they include only Greek owned corporations and profits from personal establishments are excluded. But profits for these establishments can not be so high as to exceed the extra 50 per cent increase that was used previously. In addition, in case of inclusion of personal establishments, an extra amount referring to payments to partners had to be deducted from net profits thus reducing even more their total amount. Secondly, the assumption was made in calculating the net profit figures that legal reserves have not yet amounted to one-third of equity. Dropping this assumption is not going to seriously affect the findings due to the smallness of this amount.

Comparisons then were made with the amount of 'productive investment' realized each year by large scale manufacturing on the same grounds as discussed before. Notice that data in this case are available for comparisons for both total Greece and for the Athens-Piraeus Area (otherwise called Greater Athens Area). As Table (4) indicates, for total Greece and for the period before 1972 tax exempted net profits were again much lower than the amounts of realized investment (compare Columns 2 and 8 ) and the same is true for the years following 1972 when an investment allowance was available (compare Columns 8 and 11). This suggests once more the inoperative nature of investment provisions at the margin. If one wanted to refer to comparisons for the Athens-Piraeus Area, still, with the exemption of some few years, the binding nature of investment deductions holds. This is not, though, true for investment allowances, but it is speculated that profit figures that are reported for the Athens-Piraeus Area (Column 3) simply mean that the companies' headquarters are in this Area and in reality the reported profits there correspond to branch activities in various parts of Greece; the figures of Column 3 in order to represent net profits entirely realized in this Area have to be changed considerably. While the location of investment expenditures can be identified, profit figures are difficult to decompose. Comparisons on a regional level indicate that a maximum 36 per cent investment allowance had to be in effect to assure a non-binding operation, but obviously no such case existed in the regional incentive provisions.

Since some discrepancy between net profit figures of the two procedures used has been found, which has nothing to do of course with the validity of the propositions, a final question was asked: What would net profits have to have been to make the investment provisions operative at the margin? Obviously the tax exempted net profits had to be in this case at least as much or greater than realized investment. Only in this case could marginal investments be undertaken with an assurance that tax provisions could have played an important part in the realization of these spending decisions. As noted earlier, the purpose of investment incentives is to attract these marginal investments, which could otherwise be lost if there is no margin for investment to be made cheaper. Net profits then are dependent on the percentage of available net profit allowances. In general, the minimum amount of net profits required to make allowances operative at the margin could be given by

$$
N P=I\left(\frac{1}{n}\right)
$$

where $\mathrm{NP}=$ net profits

$\mathrm{I}=$ gross investment, and

$\mathrm{n}=$ the available net profit allowance percentage.

In case an investment allowance was provided with a net profit limitation, the previous relation may be interpreted by

$$
N P=\lambda I\left(\frac{1}{n}\right)
$$

with $\lambda$ being the available percentage of investment allowance. Working with these two relations and under the specifications of various incentive laws, one can easily derive the required net profit figure that will assure operative tax provisions at the margin. These figures are presented in Columns 8 and 12 of Tables (3) and (4) respectively. Our profit figures from both procedures are indeed far less than the required amounts. Accepting the first procedure used 
as the most correct, but feeling that a high percentage (90\%) of general expenses to gross profits might have being used, it is even possible to show (see Columns 9,10 and 11 of Table 3 ) by recalling the first procedure used, that to arrive at these required net profit figures this percentage had to be on average 58 per cent which is indeed much less than the assumed rate ${ }^{17}$.

Table 4:

Net Profits And Investment Expenditures - Comparison Procedure Two (In Million Drs, At Current prices)

\begin{tabular}{|c|c|c|c|c|c|c|c|c|c|c|c|c|}
\hline \multirow[t]{3}{*}{ Year $^{1}$} & \multicolumn{2}{|c|}{$\begin{array}{l}\text { Gross } \\
\text { Investment }\end{array}$} & \multicolumn{2}{|c|}{ Net profits } & \multirow{3}{*}{$\begin{array}{l}(4) \\
(2) \\
\% \\
(5)\end{array}$} & \multirow{3}{*}{$\begin{array}{l}\text { Net } \\
\text { Profit } \\
\text { Allow- } \\
\text { ances \% } \\
\text { (6) }\end{array}$} & \multicolumn{2}{|c|}{$\begin{array}{l}\text { Tax Exempted } \\
\text { Net Profits }\end{array}$} & \multicolumn{3}{|c|}{$\begin{array}{l}\text { Investment } \\
\text { Allowances }\end{array}$} & \multirow{3}{*}{$\begin{array}{l}\text { Required } \\
\text { Net } \\
\text { Profits } \\
(12)\end{array}$} \\
\hline & \multirow{2}{*}{$\begin{array}{l}\mathrm{GA}^{2} \\
\text { (1) }\end{array}$} & \multirow{2}{*}{$\begin{array}{l}\mathrm{TG}^{2} \\
(2)\end{array}$} & \multirow{2}{*}{$\begin{array}{l}\text { GA } \\
(3)\end{array}$} & \multirow{2}{*}{$\begin{array}{l}\text { TG } \\
(4)\end{array}$} & & & \multirow{2}{*}{$\begin{array}{l}\text { GA } \\
(7)\end{array}$} & \multirow{2}{*}{$\begin{array}{l}\text { TG } \\
(8)\end{array}$} & \multirow{2}{*}{$\begin{array}{l}\% \\
(9)\end{array}$} & \multicolumn{2}{|c|}{ Amount } & \\
\hline & & & & & & & & & & $\begin{array}{l}\text { GA } \\
(10)\end{array}$ & $\begin{array}{l}\text { TG } \\
(11)\end{array}$ & \\
\hline 1958 & --- & 1342 & 289 & 307 & 22.9 & --- & --- & & & & & \\
\hline 1959 & --- & 1162 & 322 & 342 & 29.5 & 50.0 & 161 & 171 & & & & 2324 \\
\hline 1960 & --- & 1333 & 477 & 534 & 40.1 & 50.0 & 239 & 267 & & & & 2666 \\
\hline 1961 & 926 & 2083 & 593 & 651 & 31.2 & 50.0 & 296 & 326 & & & & 4166 \\
\hline 1962 & 1147 & 3027 & 649 & 714 & 23.6 & 50.0 & 324 & 357 & & & & 6054 \\
\hline 1963 & 1395 & 2959 & 779 & 861 & 29.1 & 50.0 & 389 & 431 & & & & 5918 \\
\hline 1964 & 1782 & 3268 & 1130 & 1228 & 37.6 & 50.0 & 565 & 614 & & & & 6536 \\
\hline 1965 & 3913 & 8325 & 1303 & 1409 & 16.9 & 50.0 & 651 & 705 & & & & 16650 \\
\hline 1966 & 2122 & 4475 & 1536 & 1682 & 37.6 & 50.0 & 768 & 841 & & & & 8950 \\
\hline 1967 & 1872 & 4695 & 1405 & 1573 & 33.5 & 50.0 & 702 & 787 & & & & 9390 \\
\hline 1968 & 1823 & 4511 & 1686 & 1865 & 41.3 & 100.0 & 1686 & 1865 & & & & 4511 \\
\hline 1969 & 2385 & 5565 & 2658 & 2857 & 51.3 & 100.0 & 2658 & 2857 & & & & 5565 \\
\hline 1970 & 3603 & 9094 & 4046 & 4479 & 49.2 & 100.0 & 4046 & 4479 & & & & 9094 \\
\hline 1971 & 4485 & 12036 & 4914 & 5347 & 44.4 & 100.0 & 4914 & 5347 & & & & 12036 \\
\hline 1972 & 5101 & 18201 & 6423 & 7226 & 39.7 & 100.0 & 6423 & 7226 & & & & 18201 \\
\hline 1973 & 5512 & 18593 & 11390 & 13212 & 71.1 & --- & --- & --- & & & & --- \\
\hline 1974 & $4386^{3}$ & $13805^{3}$ & 7855 & 9213 & $37.1^{4}$ & 50.0 & 3928 & 4607 & 40.0 & 1755 & 5522 & 11044 \\
\hline 1975 & $4078^{3}$ & $15871^{3}$ & 8063 & 9185 & $34.4^{4}$ & 50.0 & 4032 & 4593 & 40.0 & 1631 & 6348 & 12696 \\
\hline 1976 & 7803 & 31250 & 8658 & 10402 & 33.3 & --- & & & & & & \\
\hline 1977 & 7479 & 31790 & 7013 & 8719 & 27.4 & --- & & & & & & \\
\hline 1978 & --- & 34025 & 8302 & 10153 & 29.8 & 40.0 & 3321 & 4061 & 25.0 & --- & 8506 & 21265 \\
\hline 1979 & --- & 51618 & 18744 & 21822 & 42.3 & 40.0 & 7498 & 8729 & 25.0 & --- & 12905 & 32263 \\
\hline 1980 & --- & 63798 & 13106 & 15585 & 24.4 & 40.0 & 5242 & 6234 & 25.0 & --- & 15950 & 39875 \\
\hline \multicolumn{2}{|c|}{$\%$ Average } & & & & 36.0 & & & & & & & \\
\hline
\end{tabular}

Source: National Statistical Service of Greece, Annual Industrial Surveys, Athens, annual series, National tatistical Service of Greece, Declared Income Statistics of Legal Entities, Athens, annual series, and derivations described in text.

\footnotetext{
${ }^{1}$ For profit figures this is the accounting year, i.e. the year profits were accrued.(Greek Statistics refer to fiscal year during which income returns are filed).

${ }^{2} \mathrm{GA}=$ Greater Athens, $\mathrm{TG}=$ Total Greece.

${ }^{3}$ Refers to investment in equipment only.

${ }^{4}$ Percentages refer to total investment.
}

\section{CONCLUSION}

The examination of the effect on investment of some main incentive measures provided by the Greek authorities over the past years, has shown that these measures had not much contribution in positively influencing the rate of investment expenditure. The fiscal variables used, according to the specifications of the neoclassical theory, were the rate of corporate taxation and the fiscal parameter $\mathrm{z}$ into which changes in depreciation policy and the various tax allowances in use during all this period were incorporated. The test of fiscal parameters on investment was 
made for the two kinds of capital assets, equipment and structures, since expenditure on these two comprise on average an almost 85 per cent of total manufacturing investment in Greece.

It was indicated that the corporate tax rate had remain almost constant over the period. In addition the value of $\mathrm{z}$, incorporating depreciation allowances only, did not present any major variations for either equipment or structures. The inclusion of investment allowances $(\lambda)$ in the value of $\mathrm{z}$ and for the representative firm appeared ineffective: it was shown that investment allowances were inoperative at the margin and on an aggregate level. Thus c, the user cost of capital variable, used in the neoclassical theory for tax incentives' evaluation, is expected not to be affected much by tax provisions and in its turn may not affect decisively the desired level of capital stock and thus the amount of net investment.

\section{SUGGESTIONS FOR FUTURE RESEARCH}

Excluding, in the above sense, the neoclassical theory as a source of study of the investment behavior in Greek manufacturing, our search for the appropriate model has to be directed towards other theories of the more $a d$ hoc nature which incorporate measures of profits or the availability of internal funds as possible determinants of investment. These internal financing sources could enter in a properly specified investment function, either as determinants of the speed of adjustment of desired to actual capital stock or as determinants of the desired capital stock itself. The role of incentives then could be entered in the above framework as affecting the liquidity variables, and we could try to examine what this 'liquidity' effect of incentives could be, if any.

\section{REFERENCES}

1. Coutsoumaris, G., The Morphology of Greek Industry, Center of Planning and Economic Research, Athens, 1963.

2. Hall, R. E., Investment, Interest Rates, and the Effect of Stabilization Policies, Brookings Papers on Economic Activity, Vol.1, pp.61-103, 1977.

3. Hall, R. E. and Jorgenson, D. W., Tax Policy and Investment Behavior, American Economic Review, Vol. 57, pp. 247-259, 1967.

4. Hall, R. E. and Jorgenson, D. W., Tax Policy and Investment Behavior: Further Results, American Economic Review, Vol. 59, pp. 388-401, 1969.

5. Hall, R. E. and Jorgenson, D. W., Application of the Theory of Optimum Capital Accumulation, in Fromm, G. (ed.), Tax Incentives and Capital Spending, Brookings Institution Washington D.C.,1971.

6. Jorgenson, D.W., Anticipations and Investment Behavior, in Duesenberry, J.S. et. al. (eds.), The Brookings Quarterly Econometric Model of the United States, North Holland, Amsterdam, pp. 35-92, 1965.

7. Jorgenson, D.W., The Theory of Investment Behavior in Ferber, R. (ed.), Determinants of Investment Behavior, Columbia University Press, New York, pp. 129-156, 1967.

8. Jorgenson, D.W., The Economic Theory of Replacement and Depreciation, in Sellekaerts, W.(ed.), Essays in Honour of J. Tinbergen, North Holland, Amsterdam, 1974.

9. Jorgenson, D.W. and Siebert, C.D., A Comparison of Alternative Theories of Corporate Investment Behavior, American Economic Review, Vol. 54, pp. 681-712, 1968.

10. Jorgenson, D.W. and Stevenson, J.A., Issues in the Development of the Neoclassical Theory of Investment Behavior, Review of Economics and Statistics, Vol. 51, pp. 346-353, 1969.

11. Kottis, G.H., Industrial Decentralization and Regional Development, Institute of Economic and Industrial Research, Athens, in Greek, 1980. 


\section{ENDNOTES}

1. See Hall (1977), Hall and Jorgenson (1967, 1969, 1971), Jorgenson and Siebert (1968), Jorgenson and Strevenson (1969).

2. These rates have been derived by a very detailed and scrutinized research of various incentive laws applied in Greece for an earlier three decade period (1950-1982). We have chosen to report for this period since the very many incentive laws applied during Greece's reconstruction (following 2nd World War) have provided for various incentive measures that can be researched as to the possibility of their application. Recent incentive measures that have been legislated are mainly capital related provisions and of the grant supporting style. Incentive laws that have been searched for depreciation rate changes are: EL 942/1949, L 2901/1954, L 3765/1957, EL 147/1967, PD 88/1973, LD 1078/1971, L 1116/1981, L 1262/1982 (where L=Law, EL = Emergency Law, $\mathrm{PD}=$ Presidential Degree, $\mathrm{LD}=$ Legislative Degree) .

3. See Coutsoumaris (1963), pp.133-137, for reasons of concentration in the Athens area, and Kottis (1980), pp. 21-25.

4. The relevant incentive laws which have been searched and refer to these provisions are: EL 942/1949, LD 2176/1952, LD 3213/1955, LD 4002/1959, EL 147/1967, LD 1078/1971, LD 1212/1972, LD 1312/1972, LD 1377/1973, L 331/1974, L 289/1976, L 849/1978, L 1116/1981, L 1262/1982.

5. In fact the application of depreciation allowances alone were absorbing almost 70 per cent (buildings) or 80 percent (equipment) from net profits, with little left to be taxed if no other allowances were in use. Of course $\mathrm{z}$ refers to a present value of future deductions. But as it will be seen later the amounts of investment expenditures undertaken during all these years were much higher than the amount of profits, and deductions on these investments for depreciation purposes were carried forward so in a specific year they were reducing (if not nullifying) substantially taxable profits.

6. L 331/1974 provided for a 40\% investment allowance during 1974 and 1975, L 849/1978 provided for a $25 \%$ investment allowance during 1978 and 1979, and L 1116/1981 provided for a 20\% investment allowance during 1981 and up to 1985.

7. See the later exposition for the operative (or inoperative) nature of investment allowances.

8. See EL 147/1967 (Art.7), LD 1078/1971 (Art.3), LD 331/1974 (Art.1), L 289/1976(Art 4), L 849/1978 (Art.2), L 1116/1981 (Art.17), L 1262/1982 (Art.3)

9. These unpublished data were made available by the Center of Planning and Economic Research, Athens. An amount ranging between $16 \%$ and $21 \%$ of labor remuneration was paid each year by employers during the 1960-1980 period.

10. See Federation of Greek Industries, The State of Greek Industry, Athens, annual series. These series refer to a sample of manufacturing establishments operating under the legal form of Sociétés Anonymés (Corporations and Limited Liability Companies) whose Balance Sheets are published in the special bulletin of Government Gazette, in contrast to NSSG's Surveys which cover total manufacturing irrespective of the legal form of each unit. Given that the FGI series represent companies which produce around $85 \%$ of total manufacturing product, resort to these series could safely be made and no other data are available. Reference to FGI series at present is made simply for the derivation of a relative percentage.

11. The estimated regressions were $(\mathrm{GE})=-0.846+0.905(\mathrm{GP}), \bar{R}^{2}=0.97, \mathrm{DW}=1.80(-0.725)(26.010)$ and $(\mathrm{GEMD})=-0.509+0.694(\mathrm{GP}), \bar{R}^{2}=0.95, \mathrm{DW}=2.08(-0.472)(20.028)$ where, numbers in parentheses are $\mathrm{t}$-statistics, GE = general expenses, GP $=$ gross profits, GEMD = general expenses minus depreciation, with data covering the 1957-1980 period expressed in million drs per firm. The need to express the data per firm arose because the FGI sample varied during the period of investigation. Sensitivity analysis for the first regression equation indicated that the $95 \%$ confidence interval for the true percentage of GE to GP lay between 0.832 and 0.972 but this could be due to the smallness of the sample.

12. The estimated regression was DIV $=0.006+0.068(\mathrm{GP}), \bar{R}^{2}=0.97, \mathrm{DW}=1.93(0.079)$ (25.437) where numbers in parentheses are t-statistics, DIV = dividends and GP = gross profits, with data covering the 19571980 period expressed in million drs per firm. 
13. The use of the lower bound of the confidence interval for the true percentage of general expenses to gross profits (see endnote No 11) was checked and found to have no effect on the results and conclusions to follow.

14. This specification is given in the NSSG's statistical figures. Within these amounts, the percentage of investment expenditures for used items is in fact very small.

15. Since it was supposed that the representative firm is situated in Area A, the 50 percent of investment deduction for Area A of LD 4002/1959 was applied to total Greece's net profit figures. The 100 percent investment deduction of EL 147/1967 was the same for all Areas. The same procedure was followed for the investment allowances' percentages.

16. See consecutive issues of NSSG, Declared Income Statistics of Legal Entities(1959-1980), Athens.

17. In fact it is even smaller than the 70 percent rate that was found when gross profits were related to general expenses before depreciation.

\section{NOTES}

